\title{
RESEARCH COMMUNICATION \\ Induction of the FK506-binding protein, FKBP13, under conditions which misfold proteins in the endoplasmic reticulum
}

\author{
Kevin T. BUSH, ${ }^{\star}$ Barbara A. HENDRICKSON $†$ and Sanjay K. NIGAM ${ }^{\star} \ddagger$ \\ Harvard Medical School, *Department of Medicine (Renal Division), Brigham and Women's Hospital, and †Department of Genetics, Harvard Medical School and Division
} of Infectious Diseases, Children's Hospital, Boston, MA 02115, U.S.A.

In order to determine whether the endoplasmic reticulum (ER) luminal FK506-binding protein, FKBP13, shares properties of ER molecular chaperones, MDCK cells were treated with either tunicamycin or $\mathrm{Ca}^{2+}$ ionophores. By Northern-blot analysis, tunicamycin resulted in a 2-fold rise in FKBP13 mRNA, whereas ionophores (A23187 and ionomycin) caused a more impressive rise in FKBP13 mRNA (up to 5-fold with ionomycin). Actinomycin D chase experiments in ionomycin-treated cells revealed no change in the half-life of FKBP13 mRNA, indicating that the increase in FKBP13 mRNA observed was not due to greater message stability. Moreover, sequencing of the $5^{\prime}$ flanking region of the gene for murine FKBP13 revealed significant similarity to similar regions in human BiP (immunoglobulin-binding protein) and the human glucose-regulated protein grp94, including a 37 bp sequence in FKBP13 with 50\% identity with the unfolded protein response element of the $\mathrm{BiP}$ gene. Together, these data suggest a role for FKBP13 in ER protein folding.

\section{INTRODUCTION}

Recently, we presented evidence that the $13 \mathrm{kDa}$ FK506-binding protein (FKBP13), which has a high degree of homology to the cytoplasmic protein FKBP12, is localized to the lumen of the endoplasmic reticulum (ER) [1]. FKBP13, in addition to binding FK506, also binds the immunosuppressant drug rapamycin [2,3]. Since the lumen of the ER is the initial site of folding and assembly of secretory and transmembrane proteins, and since the highly conserved residues that comprise the peptidyl-prolylisomerase active site of FKBP12 are conserved in FKBP13 [3], the ER luminal localization of FKBP13 raises the intriguing possibility that FKBP13 could function as a molecular chaperone.

Molecular chaperones in the ER are believed to bind transiently to translocated proteins to catalyse the folding and/or multimeric assembly of transmembrane and secretory proteins [4]. Among the ER proteins thought to possess such a function are $\mathrm{BiP}$ (immunoglobulin-binding protein), the glucose-regulated protein grp94 and ERp72 [5-8]. The mRNAs for these proteins are increased by conditions associated with the accumulation of unfolded or misfolded proteins in the ER [5-7]. Furthermore, $\mathrm{BiP}$ and grp94 share similar regulatory sites in the $5^{\prime}$ flanking regions of their genes, including a $37 \mathrm{bp}$ segment believed to be responsible for the induction of $\mathrm{BiP}$ in response to protein misfolding in the ER [9,10].

We have therefore determined FKBP13 mRNA expression under conditions which cause protein misfolding in the ER, and also analysed the promoter region of the gene for FKBP13. Our findings suggest co-ordinate induction at the transcriptional level of FKBP13 with known ER molecular chaperones and support the notion that FKBP13 may play a role in protein folding in the ER [1].

\section{METHODS AND MATERIALS}

\section{Materials}

cDNA probes were kindly provided by the following investigators: FKBP13 by Steven Burakoff (Harvard Medical School/ Dana Farber Cancer Institute); ERp72 and grp94 by Michael Green (St. Louis University); PDI by Marek Michalak (University of Alberta); BiP by Mary-Jane Gething (University of Texas-Southwestern Medical Center). Antibodies against FKBP13 were kindly provided by Steven Burakoff (Harvard Medical School), against BiP by David Bole (University of Michigan), against ERp72 and grp94 by Michael Green (St. Louis University), and against PDI by Charlotte Kaetzel (Case Western Reserve University).

\section{Treatment conditions, Northern-blot analysis and actinomycin D chase}

Confluent monolayers of Madin-Darby canine kidney (MDCK) cells growing in Dulbecco's minimal essential medium (DMEM; Gibco) containing $5 \%$ fetal-calf serum were incubated in either (1) fresh DMEM containing $2 \mu \mathrm{g} / \mathrm{ml}$ or $10 \mu \mathrm{g} / \mathrm{ml}$ tunicamycin or (2) fresh minimal essential medium supplemented with dialysed $5 \%$ fetal-calf serum [11], and containing either $5 \mu \mathrm{M}$ A23187 or $5 \mu \mathrm{M}$ ionomycin. Total RNA was isolated by phenol/chloroform extraction [12] at 4, 8, 12, 16 and $24 \mathrm{~h}$ after treatment with the drugs. RNA $(5 \mu \mathrm{g})$ was electrophoresed on $1 \%$ formamide/ formaldehyde agarose gels, transferred to nitrocellulose and hybridized with random-primed ${ }^{32} \mathrm{P}$-labelled cDNA [13]. In addition, actinomycin $\mathrm{D}$ chase experiments were performed. Briefly, control and ionomycin-treated ( $5 \mu \mathrm{M})$ MDCK cells were exposed to actinomycin D $\{20 \mu \mathrm{g} / \mathrm{ml}$, which inhibited RNA synthesis, measured by $\left[{ }^{3} \mathrm{H}\right]$ uridine uptake, by $>95 \%$ (results

Abbreviations used: FKBP, FK506-binding protein; ER, endoplasmic reticulum; BiP, immunoglobulin-binding protein; grp, glucose-regulated protein; ERp, ER protein; PDI, protein disulphide-isomerase; MDCK, Madin-Darby canine kidney; LDH, lactate dehydrogenase.

$\ddagger$ To whom correspondence should be addressed, at: Renal Division, Brigham and Women's Hospital, Harvard Medical School, 75 Francis Street, Boston, MA 02115, U.S.A. 
not shown)]. Total RNA was isolated and processed as described above at 1,2 and $4 \mathrm{~h}$ after treatment with actinomycin $\mathrm{D}$.

\section{Immunoblot protein analysis}

After growth in the presence of drugs, the medium was collected, cells were extracted [14], and protein samples were electrophoresed on a SDS $/ 13 \%$-polyacrylamide gel, subjected to Western blotting, probed with primary antisera, and developed as previously described $[14,15]$. In order to determine if any protein found in the conditioned media was the result of cell death, the media were assayed for lactate dehydrogenase (LDH) activity colorimetrically by using a LDH assay kit (Sigma).

\section{Sequence analysis}

The murine FKBP13 genomic clone ( $3 \mu \mathrm{g})$ isolated as previously described in pBluescript $(+)[16]$ was sequenced by the dideoxynucleotide chain-termination method using the Sequenase enzyme (U.S. Biochemical Corp.) and analysed by using Geneworks (Intelligenetics).

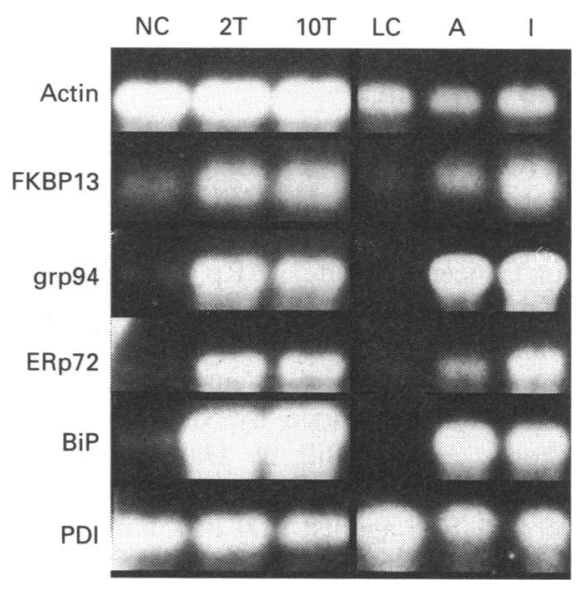

Figure 1 FKBP13 mRNA expression is co-ordinately increased with mRNA for putative ER molecular chaperones

Northern-blot analysis of total RNA from MDCK cells grown for $12 \mathrm{~h}$ in the absence (NC, normal$\mathrm{Ca}^{2+}$ control) or presence of tunicamycin $(2 \mathrm{~T}, 2 \mu \mathrm{g} / \mathrm{ml} ; 10 \mathrm{~T}, 10 \mu \mathrm{g} / \mathrm{ml})$ and in the absence (LC, low- $\mathrm{Ca}^{2+}$ control) or presence of $\mathrm{Ca}^{2+}$ ionophores (A, $5 \mu \mathrm{M}$ A23187; I, $5 \mu \mathrm{M}$ ionomycin). Blots were probed with ${ }^{32}$ - -labelled $\mathrm{CDNA}$ probes for the gene products indicated at the left 0 the Figure.

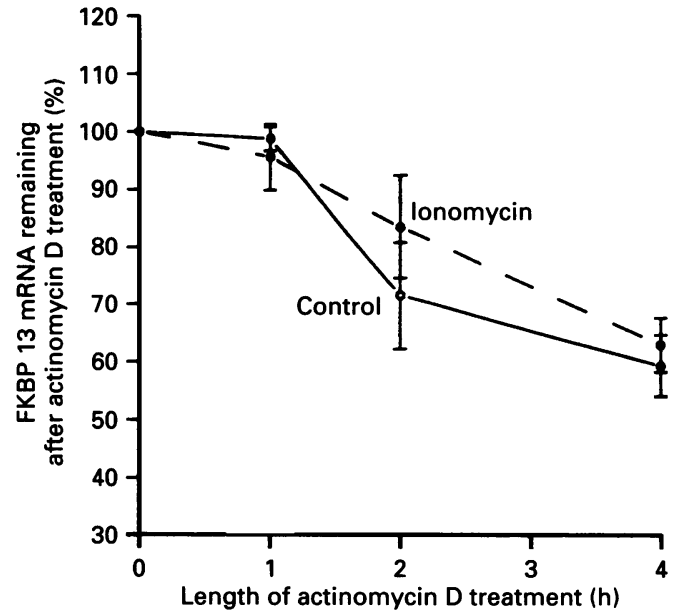

\section{Figure 2 FKBP13 mRNA half-life}

Graph showing percentage of FKBP13 mRNA remaining after 1, 2 and $4 \mathrm{~h}$ of exposure to actinomycin $\mathrm{D}$ in MDCK cells grown for $12 \mathrm{~h}$ in media with $(O)$ or without $(O)$ ionomycin $(5 \mu \mathrm{M})$. Northern blots were probed with ${ }^{32}$ P-labelled cDNA probes for glyceraldehyde-3phosphate dehydrogenase (to quantify the gel load and normalize the mRNA levels) and FKBP13. Amounts of mRNA were quantified by densitometric analysis. Percentages were determined by comparing with zero time $(100 \%=$ no actinomycin $D$ treatment $)$.

\section{RESULTS AND DISCUSSION}

Treatment of animal cells with either tunicamycin, which inhibits $\mathrm{N}$-linked glycosylation, or $\mathrm{Ca}^{2+}$ ionophores (A23187 or ionomycin), which deplete intracellular $\mathrm{Ca}^{2+}$, is believed to result in accumulation of misfolded proteins in the ER and induction of transcription of the genes for BiP, grp94 and ERp72 [4-7,9,10]. To determine whether FKBP13 is also inducible under these conditions, MDCK cells were treated with either tunicamycin or $\mathrm{Ca}^{2+}$ ionophores (A23187 and ionomycin), and total cellular RNA was subjected to Northern analysis in order to determine the levels of mRNAs for FKBP13, BiP, grp94, ERp72, protein disulphide-isomerase (PDI) and actin (Figure 1). Treatment of MDCK cells with tunicamycin ( 2 or $10 \mu \mathrm{g} / \mathrm{ml}$; equivalent results were obtained for either concentration) or $\mathrm{Ca}^{2+}$ ionophores produced significant and consistent increases in the mRNA levels for BiP, grp94 and ERp72, whereas the mRNA for PDI was induced minimally, if at all (Figure 1; Table 1). These results were consistent with previous studies which showed levels of induction for mRNAs encoding these proteins as follows: BiP >

\section{Table 1 inquction of mRNA after treatment of MDCK cells with tunicamycin or $\mathrm{Ca}^{2+}$ ionophores}

Induction was determined by dividing values for treated cells by those for untreated and normalizing with actin mRNA level. Only data for $10 \mu \mathrm{g} / \mathrm{ml}$ tunicmycin are shown; results for $2 \mu \mathrm{g} / \mathrm{ml}$ were comparable. Data for 4 and $24 \mathrm{~h}$ not shown. Results are means \pm S.E.M. ( $n=4$ experiments). Abbreviations: TUNICA, tunicamycin; IONO, ionomycin.

\begin{tabular}{|c|c|c|c|c|c|c|c|c|c|}
\hline \multirow[t]{2}{*}{ Treatment time... } & \multicolumn{3}{|l|}{$8 \mathrm{~h}$} & \multicolumn{3}{|l|}{$12 \mathrm{~h}$} & \multicolumn{3}{|l|}{$16 \mathrm{~h}$} \\
\hline & TUNICA & A23187 & IONO & TUNICA & A23187 & IONO & TUNICA & A23187 & IONO \\
\hline $\begin{array}{l}\text { FKBP13 } \\
\text { grp94 } \\
\text { ERp72 } \\
\text { BiP } \\
\text { PDI }\end{array}$ & $\begin{array}{c}1.5 \pm 0.3 \\
6.6 \pm 2.1 \\
2.5 \pm 0.9 \\
17.9 \pm 8 \\
0.9 \pm 0.3\end{array}$ & $\begin{array}{r}2.6 \pm 0.2 \\
5.8 \pm 0.5 \\
5.6 \pm 3.7 \\
13.3 \pm 2.8 \\
1.2 \pm 0.1\end{array}$ & $\begin{array}{r}2.2 \pm 0.3 \\
7.2 \pm 0.5 \\
8.4 \pm 6.8 \\
13.4 \pm 2.9 \\
1.2 \pm 0.1\end{array}$ & $\begin{array}{c}2.0 \pm 0.7 \\
9.8 \pm 0.1 \\
5.8 \pm 3 \\
12.2 \pm 3.3 \\
1.0 \pm 0.3\end{array}$ & $\begin{array}{r}2.3 \pm 0.8 \\
8.6 \pm 5.6 \\
3 \pm 1.1 \\
8.0 \pm 2.2 \\
0.5 \pm 0.2\end{array}$ & $\begin{array}{c}2.6 \pm 0.6 \\
11 \pm 7 \\
3.4 \pm 2.8 \\
6.6 \pm 3.5 \\
0.9 \pm 0.7\end{array}$ & $\begin{array}{r}1.8 \pm 0.3 \\
9.9 \pm 2.2 \\
8.5 \pm 0.9 \\
26.6 \pm 8.3 \\
1.4 \pm 0.3\end{array}$ & $\begin{array}{l}3.0 \pm 0.5 \\
4.6 \pm 2.1 \\
2.1 \pm 0.1 \\
9.4 \pm 2.3 \\
1.1 \pm 0.4\end{array}$ & $\begin{array}{c}4.7 \pm 1.6 \\
8.2 \pm 5 \\
4.1 \pm 0.5 \\
16.7 \pm 8.7 \\
1.8 \pm 0.6\end{array}$ \\
\hline
\end{tabular}




$$
\text { (a) }
$$

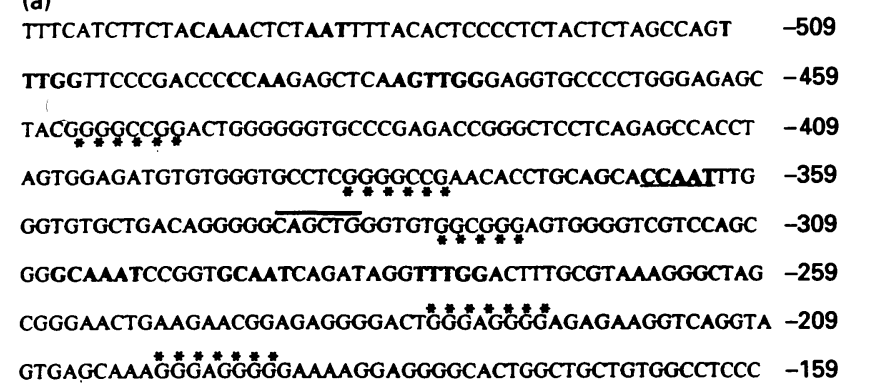

CTGACCCCCTCCCCTCGCTGCTGGGGTCCTCGGTCAAGCCCСCTTCTCAC $\quad-109$

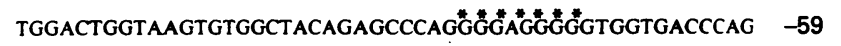

GACTGTGGGATTCCCCAGAACAGGCAAGATATAATGGGGAGTTGGCGTC -9

CTCCTGATACAGACTGAAGACGTCCCATGACTCCACCCCCCAGTTTTTTG 41

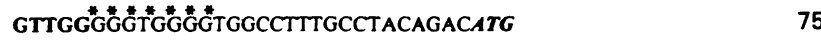

(b)

hgrp94

hBiP

MFKBP13

hgrp94

Consensus (a)

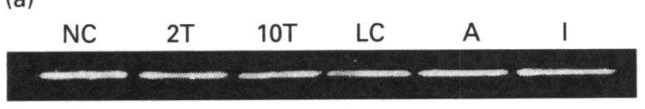

(b)

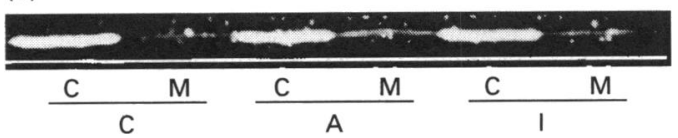

Figure 4 (a) FKBP13 protein levels are unchanged, and (b) FKBP13 protein is not significantly secreted, after treatment with tunicamycin and $\mathrm{Ca}^{2+}$ ionophores

(a) Western-blot analysis of the steady-state cellular levels of FKBP13 protein in MDCK cells incubated for $16 \mathrm{~h}$ in the absence (NC, normal- $\mathrm{Ca}^{2+}$ control) or presence of tunicamycin (2T, $2 \mu \mathrm{g} / \mathrm{ml} ; 10 \mathrm{~T}, 10 \mu \mathrm{g} / \mathrm{ml}$ ) and in the absence (LC, low- $\mathrm{Ca}^{2+}$ control) or presence of $\mathrm{Ca}^{2+}$ ionophores (A, $5 \mu \mathrm{M}$ A23187; I, $5 \mu \mathrm{M}$ ionomycin). Blots were probed with antibody against human FKBP13. Steady-state levels of BiP and grp94 were increased $<1.5$-fold. (b) Westernblot analysis of levels of FKBP13 protein in MDCK cells $(C)$ and growth medium (M) after $16 \mathrm{~h}$ of incubation in the absence ( $C$, control) or presence of $\mathrm{Ca}^{2+}$ ionophores $(A, 5 \mu \mathrm{M} \mathrm{A23187}$; I. $5 \mu \mathrm{M}$ ionomycin). In all cases, $<10 \%$ of the protein was detected in the medium. Colorimetric determination of LDH activity of the culture media revealed no difference in activity between controls and MDCK cells grown for $16 \mathrm{~h}$ in the presence of $5 \mu \mathrm{M}$ ionomycin.

for BiP and grp94, consistent with what has been reported previously [17]\}. In order to determine if the accumulation of FKBP13 mRNA was due to an increase in message stability, actinomycin D chase experiments were performed. A concentration of $20 \mu \mathrm{g} / \mathrm{ml}$ actinomycin D resulted in $95 \%$ inhibition of mRNA synthesis in MDCK cells, as determined by [ ${ }^{3} \mathrm{H}$ ]uridine uptake (results not shown). At this concentration of actinomycin $\mathrm{D}$, treatment of MDCK cells with ionomycin [5 $\mu \mathrm{M}$, a treatment which resulted in greatest increase in the mRNA for FKBP13 (Figure 1; Table 1)] was found to have no effect on the half-life of the mRNA for FKBP13 (Figure 2). This result suggests that the increase in FKBP13 mRNA is not due to an increase in the stability of the mRNA and probably reflects transcriptional regulation.

These results suggest that the gene for FKBP13 is transcriptionally activated under conditions which activate transcription of BiP, grp94 and ERp72, and raise the possibility that these genes respond to some common stimulus brought about by physiological stress. The $5^{\prime}$ flanking regions of the genes for $\mathrm{BiP}$ and grp94 share strong similarity, including several putative transcriptional regulatory sites [18-20] and the region believed to be responsible for the induction of BiP by unfolded proteins in the ER $[9,10,21]$. Since FKBP13 is co-ordinately regulated with the gene products for these chaperones, we analysed the $5^{\prime}$ flanking region of its gene for similar sequences. A $3 \mathrm{kbp}$ genomic clone encoding the murine FKBP13 gene [16] was sequenced 509 bp $5^{\prime}$ to the approximate transcription start site (Figure 3a) and compared with the $5^{\prime}$ flanking region of the genes for human BiP and human grp94. We found that the murine FKBP13 sequence shared significant similarity to corresponding human sequences in BiP and grp94 (Figures $3 \mathrm{a}$ and 3b; Table 2), including a number of putative transcriptional regulatory sites (Table 2) $[9,19]$. Among these are interrupted poly $(\mathbf{G})$ sequences, which have been suggested to function as recognition sites for transcriptional control [20]. For example, the sequence GGGNNGGG (where $\mathrm{N}$ is any base), which occurs multiple times in the promoter regions of FKBP13 (Figure 3a; Table 2),

BiP and grp94 $[9,20]$, has been described in chicken globin genes grp94 $>$ ERp72 $\gg$ PDI [5]. FKBP13 mRNA levels were found to increase with both tunicamycin (2-fold) and $\mathrm{Ca}^{2+}$ ionophores (up to 5-fold) (Figure 1; Table 1). Moreover, the increase in FKBP13 $\mathrm{mRNa}$ after $16 \mathrm{~h}$ of treatment with $\mathrm{Ca}^{2+}$ ionophores was comparable with that observed for ERp72 mRNA (Table 1). Nevertheless, FKBP13 protein levels were not increased (Figure 4a) only a slight increase in protein levels $(<1.5$-fold $)$ was observed 
as a nuclear transcription factor-binding site [20,22,23]. Furthermore, palindromes, such as CAGCTG, which is present in both FKBP13 (Figure 3a; Table 2) and BiP [20], are thought to be binding sites of transcriptional regulatory proteins. Thus the FKBP13 gene shares a number of similar putative transcriptional regulatory domains with the genes for $\mathrm{BiP}$ and grp94. In addition, a $37 \mathrm{bp}$ sequence in the $5^{\prime}$-untranslated region of murine FKBP13 was found to have $\sim 50 \%$ identity with the putative unfolded protein response element (UPR) of human BiP (Figure 3b). Although it remains to be determined if this sequence is actually the UPR for FKBP13 in mammalian cells, taken together with the other sequence data, these findings do suggest a possible mechanism for the co-ordinate transcriptional regulation of FKBP13 with other ER molecular chaperones in response to unfolded proteins.

There has been some debate surrounding the effects of tunicamycin and $\mathrm{Ca}^{2+}$ ionophores on the steady-state level and cellular localization of ER-resident proteins. Ionophore A23187 has been reported to decrease the protein levels of BiP and PDI in NIH 3T3 cells, apparently due to secretion of these ER luminal proteins as a result of ER $\mathrm{Ca}^{2+}$ depletion [24]. We therefore analysed FKBP13 protein levels after ionophore and tunicamycin treatment. In MDCK cells, Western-blot analysis indicated that there was minimal $(<10 \%)$ secretion of FKBP13 into the medium (Figure 4b). There was no increase in LDH activity in the media after ionomycin treatment, indicating that the apparent secretion of FKBP13, albeit very small, was not the consequence of cell death. Furthermore, none of the other proteins that we examined (BiP, grp94, ERp72 and PDI) appeared to be appreciably induced (protein level) or significantly secreted (results not shown).

Thus our data indicate that FKBP13 shares an important distinguishing characteristic of ER molecular chaperones (i.e., induction in response to the accumulation of misfolded proteins in the ER) and support the notion that FKBP13 may play a role in protein folding in the ER. Moreover, these results are compatible with the intriguing possibility that FKBP13 and rapamycin could exert some of their effects by interfering with protein folding in the ER [1].
We thank Dr. Steven Burakoff, Dr. John Seidman and Dr. Barbara Bierer for their advice and critical reading of the manuscript, and Dr. Galina Kuznetzov, Dr. Michael Rauchman, Dr. Eric Delpire and Dr. Steven Gullans for their methodological help. K. T. B. is supported by NIH Institutional Training Grant 5-T32-DK07527-09. B. A. H. is supported by a NIAID Physician Scientist Award. S. K. N. is supported by NIH grant R01 DK44503-01A1.

\section{REFERENCES}

1 Nigam, S. K., Jin, Y. J., Jin, M. J., Bierer, B. E., Bush, K. T. and Burakoff, S. J. (1993) Biochem. J. 294, 511-515

2 Jin, Y. J., Albers, M. W., Lane, W. S., Bierer, B. E., Schreiber, S. L. and Burakoff, S. J. (1991) Proc. Natl. Acad. Sci. U.S.A. 88, 6677-6681

3 Bierer, B. E., Jin, Y. J., Fruman, D. A., Calvo, V. and Burakoff, S. J. (1991) Transplant. Proc. 23, 2850-2855

4 Gething, M. J. and Sambrook, J. F. (1992) Nature (London) 355, 33-45

5 Dorner, A. J., Wasley, L. C., Raney, P., Haugejorden, S., Green, M. and Kaufman, R. J. (1992) J. Biol. Chem. 265, 22029-22034

6 Mori, K., Sant, A., Kohno, K., Normington, K., Gething, M. J. and Sambrook, J. F. (1992) EMBO J. 11, 2583-2593

7 Cox, J. S., Shamu, C. E. and Walter, P. (1993) Cell 73, 1197-1206

8 Nigam, S. K., Goldberg, A. L., Ho, S., Rohde, M. F., Bush, K. T. and Sherman, M. Y. (1994) J. Biol. Chem. 269, 1744-1749

9 Chang, C. S., Erwin, A. and Lee, A. S. (1989) Mol. Cell. Biol. 9, 2153-2162

10 Li, X. and Lee, A. S. (1991) Mol. Cell. Biol. 11, 3446-3453

11 Nigam, S. K., Denisenko, N., Rodriguez-Boulan, E. and Citi, S. (1991) Biochem. Biophys. Res. Commun. 181, 548-553

12 Gough, N. M. (1988) Anal. Biochem. 173, 93-95

13 Sambrook, J., Fritsch, E. F. and Maniatis, T. (1989) Molecular Cloning: A Laboratory Manual, 2nd edn., Cold Spring Harbor Laboratory, Cold Spring Harbor, NY

14 Stuart, R. 0., Sun, A., Panichas, M., Hebert, S. C., Brenner, B. M. and Nigam, S. K. (1994) J. Cell. Physiol. 159, 323-333

15 Nigam, S. K. and Blobel, G. (1989) J. Biol. Chem. 264, 16927-16932

16 Hendrickson, B. A., Zhang, W., Craig, R. J., Jin, Y. J., Bierer, B. E., Burakoff, S. and Dilella, A. G. (1993) Gene 134, 271-275

17 Lodish, H. F. and Kong, N. (1990) J. Biol. Chem. 265, 10893-10899

18 Ting, J. and Lee, A. S. (1988) DNA 7, 275-286

19 Tasanen, K., Oikarinen, J., Kivirikko, K. I. and Pihlajaniemi, T. (1992) J. Biol. Chem. 267, 11513-11519

20 McCauliffe, D. P., Yang, Y. S., Sontheimer, R. D. and Capra, J. D. (1992) J. Biol Chem. 267, 2557-2562

21 Resendez, E., Wooden, S. K. and Lee, A. S. (1988) Mol. Cell. Biol. 8, 4579-4584

22 Kemper, B., Jackson, P. D. and Felsenfeld, G. (1987) Mol. Cell. Biol. 7, 2059-2069

23 Emerson, B. M., Lewis, C. D. and Felsenfeld, G. (1985) Cell 41, 21-30

24 Booth, C. and Koch, G. L. E. (1989) Cell 59, 729-737 